\title{
Hospital acquired pneumonia: Issues in therapy
}

LIONEL A MANDELL MD FRCPC

\begin{abstract}
LA Mandell. Hospital acquired pneumonia: Issues in therapy. Can J Infect Dis 1994;5(Suppl C):15C-19C. In December 1992, a meeting was convened in Toronto to develop guidelines for the initial treatment of hospital acquired pneumonia. Issues considered related to the patient, the possible drugs used for treatment, and the pathogen(s). From the perspective of the patient, the two major issues were the presence or absence of risk factors for specific microbial pathogens and the severity of illness upon clinical presentation. Criteria for defining severly ill patients were developed and are presented in this paper. Drug and pathogen related issues focused on selection of antimicrobial agents that would provide coverage for the likely pathogens. Concern was also expressed regarding use of aminoglycosides as single-agent treatment of Gram-negative infections in the lung, and the issue of monotherapy versus combination therapy of Pseudomonas aeruginosa infections was discussed. The use of various diagnostic tests was briefly reviewed, including the protected specimen brush and bronchoalveolar lavage. Treatment regimens are presented in tabular format.
\end{abstract}

Key Words: Hospital acquired pneumonia, Treatment guidelines

\section{Pneumonie en milieu hospitalier : enjeux thérapeutiques}

RÉSUMÉ : À Toronto, en décembre 1992, s'est tenue une réunion au cours de laquelle ont été rédigées des directives concernant le traitement initial des pneumonies acquises en milieu hospitalier. Les discussions ont porté sur le patient, les médicaments composant l'arsenal thérapeutique et le(s) pathogène(s) en cause. Du point de vue du patient, les deux principales questions ont été la présence ou l'absence de facteurs de risque à l'égard de certains organismes pathogènes précis et la gravitè de la maladie, représentée par le tableau clinique. Des critères servant à définir les grands malades ont été fixés et sont présentés dans ces pages. Les questions liées aux pathogènes et aux médicaments ont porté sur la sélection des antimicrobiens les plus susceptibles d'offrir une couverture adéquate contre les pathogènes les plus probables. On a formulé des inquiétudes au sujet de l'emploi des aminoglycosides en monothérapie dans les infections pulmonaires Gram négatives, et les caractéristiques de la monothérapie et de la polythérapie ont été respectivement comparées dans le contexte des infections à Pseudomonas aeruginosa. Les diverses épreuves diagnostiques possibles ont brièvement étê passées en revue, y compris le brossage protégé avec lavage bronchoalvéolaire. Les schémas thérapeutiques sont présentés sous forme de tableaux.

Division of Infectious Diseases, McMaster University. Hamilton, Ontario

Correspondence and reprints: Dr LA Mandell, McMaster Medical Unit, Henderson General Hospital, 711 Concession Street, Hamilton, Ontario LSV IC3 
$\mathrm{I}^{\mathrm{N}}$ N NOVEMBER 1991. A CONSENSUS CONFERENCE WAS HELD in Halifax, Nova Scotia to develop guidelines for the initial antimicrobial treatment of community acquired pneumonia (CAP). The resulting manuscript was published in the Canadian Journal of Infectious Diseases (1) and formed the basis of a similar conference sponsored by the American Thoracic Society (ATS), which resulted in the publication of an official ATs statement (2). It was felt that the next step in this process should be the development of guidelines for initial antimicrobial treatment of hospital acquired pneumonia (HAP). Accordingly, a conference was held in December 1992 in Toronto with representatives from Canada, the United States and the United Kingdom taking part. These guidelines were recently published in the Canadian Journal of Infectious Diseases, and the ATs has undertaken a similar process (3).

Sections of the guidelines are reprinted from the Journal and are incorporated into this article. It was felt that a forum such as this was appropriate to present in greater detail some of the issues that formed the basis of the guidelines. Obviously, one can deal with HAP in a number of ways, but which is the best way when attempting to develop a simple, straightforward approach? To be useful, the guidelines must be as simple, straightforward and easy to use as possible.

The various issues considered relate to the patient, the drugs and the pathogen(s). These three entities together form an interactive triad.

\section{PATIENT RELATED ISSUES}

As far as the patient is concerned, two major issues were considered. These were the presence or absence of risk factors for specific microbial pathogens, and the severity of illness upon clinical presentation. It is clear from a number of studies that certain risk factors predispose patients to the development of nosocomial pneumonia (4-6). In a study by Haley et al (4), numerous risk factors were identified that were associated with the development of pneumonia, and risk of infection was directly related to duration of both surgery and of hospitalization. There was also a greater likelihood of nosocomial pneumonia occurring in patients who had upper abdominal and/or thoracic surgery than in patients who had surgery involving other areas. In a study by Craven (5) involving mechanically ventilated patients, risk factors for ventilator associated pneumonia were identified by univariate analysis. Factors such as use of an intracranial pressure monitor, craniotomy, head trauma, use of cimetidine, $24 \mathrm{~h}$ circuit changes, infection in the fall/winter season, steroid treatment and coma were all associated with an increased risk of infection. In another study, the investigators looked at episodes of nosocomial pneumonia in ventilated patients and tried to identify factors increasing the incidence, risk and prognosis of ventilator associated pneumonia (6). Certain factors were suggested by logis- tic regression analysis to be independently associated with a high risk of developing pneumonia during mechanical ventilation. These were: reintubation; gastric aspiration; mechanical ventilation lasting longer than three days; and the presence of chronic obstructive pulmonary disease.

In a study by Rello (7), 161 multiple trauma patients were followed prospectively in order to determine the incidence, causative agents and outcome of nosocomial pneumonia. In the group of patients with coma lasting longer than $24 \mathrm{~h}$ who developed pneumonia, Staphylococcus aureus was found to be a very significant pathogen, occurring in $55.8 \%$ of cases. Another type of risk factor was identified in a prospective study of 567 patients who had been receiving mechanical ventilation longer than three days (8). In patients who had received prior antimicrobial therapy, there was a higher incidence of pneumonia due to Pseudomonas aeruginosa or Acinetobacter species. The mortality rate in these patients was much higher than that seen with other pathogens $(87 \%$ versus $69 \%)(\mathrm{P}<0.01)$.

There are very few published studies that specifically define severity of illness for nosocomial pneumonia. Therefore, it was decided to extrapolate from data on CAP. Several of these features have been identified in a study of risk and prognosis in patients with nosocomial pneumonia (9). Patients may be considered to be severely ill if they present with any of the following: respiratory failure $\left(\mathrm{PaO}_{2}\right.$ less than $60 \mathrm{mmHg}$ on an $\mathrm{FiO}_{2}$ greater than 35\% with the exception of patients with chronic obstructive airway disease who may be hypoxemic without pneumonia); respiratory rate 30 or more breaths/min; sepsis with evidence of end-organ dysfunction (severe sepsis); extrapulmonary septic complications; cavitation or involvement of more than one lobe on chest radiograph. For practical purposes, it is best to consider any patient with pneumonia who is being mechanically ventilated as having a severe infection.

\section{DRUG AND PATHOGEN RELATED ISSUES}

As far as drug related issues are concerned, the main consideration was to use antimicrobial agents that would provide coverage for the likely pathogens. The latter include aerobic Gram-negative bacilli (including $P$ aeruginosa), S aureus (methicillin-sensitive and resistant), anaerobes and Legionnella pneumophila. A number of drugs would fit this description, and in all cases. consideration must first be given to efficacy, then to toxicity or adverse events and finally to cost.

There was some concern about the use of aminoglycosides as single-agent therapy for Gram-negative infections in the lung. Studies have shown that aminoglycosides do not achieve particularly high levels in lung tissue, and there is also concern that in the acidic endobronchial milieu of infected lungs, the antimicrobial activity of aminoglycosides may be reduced (10,11). 
TABLE 1

Initial treatment options for hospital acquired pneumonia

Clinical presentation - mild to moderate; risk factors present

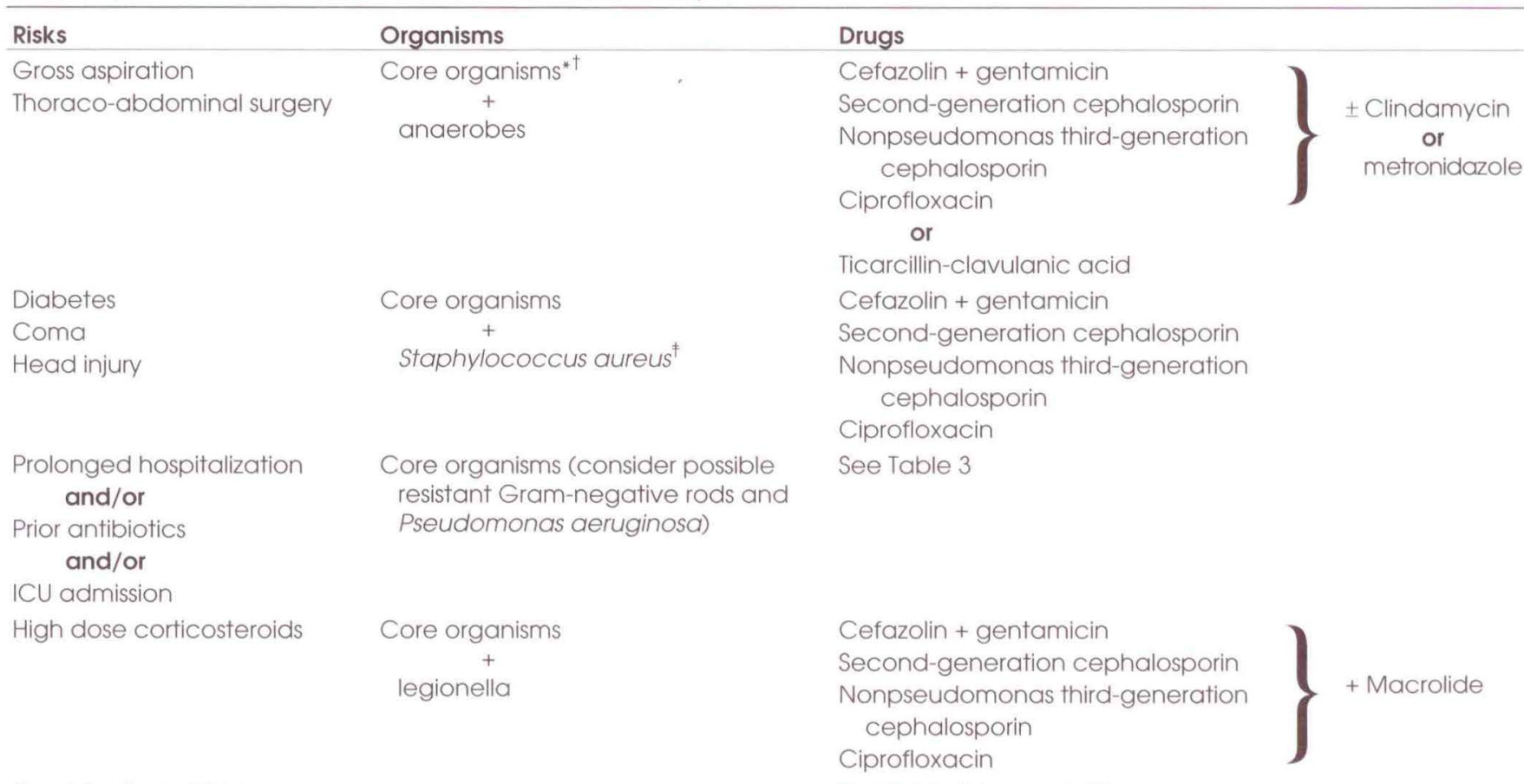

Combination of risks

See Table 3 (severely ill)

ICU Intensive care unit; "Core organisms are listed in Table 2: ${ }^{\dagger}$ If the likely pathogen is an Enterobacter species, a cephalosporin should not be used regardless of in vitro susceptibility results; ${ }^{\dagger}$ If methicillin-resistant $S$ aureus is prevalent in your institution, consider adding vancomycin. Reproduced from Can J Infect Dis 1993:4:318

With regard to the issue of monotherapy versus combination therapy for nonpseudomonal infection, there are data to show that single drug therapy is efficacious (12). There is reluctance, however, to treat $P$ aeruginosa pneumonia with only one agent. One study showed that the mortality of nosocomial pneumonia in an intensive care unit was 33\% in patients not infected with pseudomonas and $70 \%$ in patients infected with this pathogen (13). Another study of 172 episodes of bacteremia secondary to nosocomial pneumonia showed that when pseudomonas was the pathogen, the mortality rate was $72 \%$ (14). In a study by Hilf et al (15), outcome correlations for combination or singledrug treatment of pseudomonas bacteremia were examined prospectively in 200 patients. In those with pneumonia, the percentage mortality in those treated with combination therapy was $35 \%$, whereas for patients treated with a single drug, the percent mortality was $88 \%(\mathrm{P}=0.03)$.

\section{DIAGNOSTIC ISSUES}

The etiological pathogens responsible for nosocomial pneumonia differ substantially from those causing CAP. Organisms such as Streptococcus pneumoniae, Mycoplasma pneumoniae and Chlamydia pneumoniae are frequent pathogens in CAP while aerobic Gram-negative rods and S aureus account for the majority of HAP cases $(16,17)$. In patients who have impaired consciousness or other neurological conditions that may predispose to aspiration, anaerobes should also be considered to be potential pathogens.

Depending on the method used to determine microbial etiology, results may vary from study to study. Using the protected specimen brush, sputum cultures or blood cultures, however, Gram-negative organisms account for $61 \%$ to $75 \%$ of pathogens and $S$ aureus for $22 \%$ to $33 \%$ (16). Of the Gram-negative pathogens, $P$ aeruginosa is the single most common organism, particularly in ventilated patients (16). Specific organisms that may be associated with particular risk factors are listed in Table 1.

The diagnosis of nosocomial pneumonia requires the synthesis of information obtained from a careful history, physical examination and appropriate laboratory tests and/or procedures. The history should identify any comorbid conditions and risk factors. The physician must also be careful to consider any noninfectious causes of fever and pulmonary infiltrates that may confound the picture. If possible, a good quality expectorated or suctioned sputum sample for Gram stain and culture should be obtained. Invasive procedures such as bronchoscopy are not usually necessary for most cases during the initial evaluation. Blood should be drawn for determination of a complete blood cell count and differential, and two sets of blood cultures should be collected as well. Routine radiological exami- 
TABLE 2

Initial treatment options for hospital acquired pneumonia

Clinical presentation - mild to moderate; no unusual risk factors

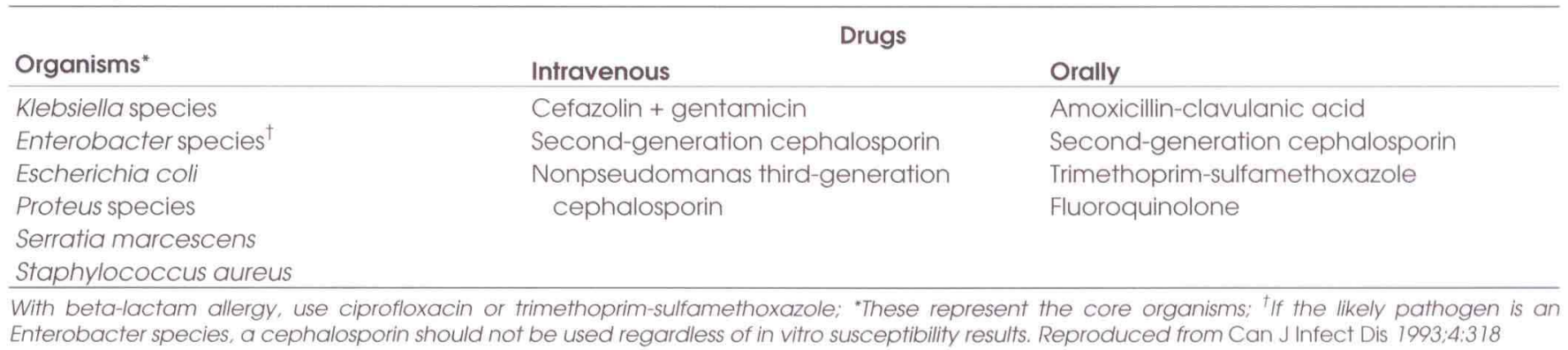

TABLE 3

Initial treatment options

Clinical presentation - severe

\begin{tabular}{ll}
\hline Organisms & Pseudomonas aeruginosa \\
& Klebsiella species \\
& Enterobacter species \\
& Escherichia coli \\
& Proteus species \\
& Serratia marcescens \\
& Staphylococcus aureus* \\
& Legionella pneumophila \\
& Intravenous \\
& Broad spectrum beta-lactam or fluoroquinolone \\
Drugs & with activity against Paeruginosa \\
& Piperacillin \\
& Ceftazidime \\
& Imipenem/cilastatin \\
& Ticarcillin/clavilanic acid \\
& Ciprofloxacin
\end{tabular}

"If methicillin-resistant S qureus is prevalent in your institution, consider adding vancomycin: ${ }^{\dagger}$ May be a nosocomial pathogen. If so, add a macrolide; ${ }^{\dagger}$ Other combinations may be considered, eg, ceftazidime/ ciprofloxacin. Reproduced from Can J Infect Dis 1993:4:379

nation should include a posteroanterior and lateral chest radiograph. In patients who are intubated, a more aggressive approach to diagnosis may be necessary. In such cases, where expertise exists, use of both protected specimen brush technique and bronchoalveolar lavage are options to be considered (18). Gram stain of centrifuged bronchoalveolar lavage fluid may then be used as a guide to initial empirical antibiotic therapy (18).

\section{TREATMENT}

Based on the variables discussed above, the various treatment options are presented in Tables 1, 2 and 3. Wherever possible, we have used classes of drugs rather than individual agents (see Appendix). However, if only one drug in a given class was available or considered suitable, then that specific drug name has been used. Tables 1 and 2 deal with patients with mild to moderate infections who have either no unusual risk factors (Table 2) or in whom risk factors for specific

Appendix
Antibiotics for the treatment
monia

"Orally: ${ }^{\dagger}$ Intravenous

pathogens may be present (Table 1). Table 3 deals with patients with severe HAP.

In all cases, whenever additional information such as culture and susceptibility data that may affect treatment become available, the attending physician should amend or modify the initial regimen as necessary. Attention must also be paid to supportive treatment including management of fluid and electrolyte balance, oxygenation and management of any complications that may arise. 


\section{REFERENCES}

1. Mandell LA, Niederman M, The Canadian Community Acquired Pneumonia Consensus Conference Group. Antimicrobial treatment of community acquired pneumonia in adults: A conference report. Can J Infect Dis 1993;4:25-8.

2. Niederman MS, Bass JB, Campbell GD, et al. Guidelines for the initial empiric therapy of community acquired pneumonia: proceedings of an American Thoracic Society Consensus Conference. Am Rev Respir Dis 1993; 148:1418-26.

3. Mandell LA, Marrie TJ, Niederman M, The Canadian Hospital Acquired Pneumonia Consensus Conference Group. Initial antimicrobial treatment of hospital acquired pneumonia in adults: a conference report. Can J Infect Dis 1993:4:317-21.

4. Haley RW, Hooten TM, Culver D, et al. Nosocomial infections in US Hospitals, 1975-1976: Estimated frequency by selected characteristics of patients. Am J Med 1981;70:947-59.

5. Craven DE, Kunches LM, Kilinsky V, et al. Risk factors for pneumonia and fatality in patients receiving continuous mechanical ventilation. Am Rev Respir Dis 1986;133:792-6.

6. Torres A, Aznar R, Gatell JM, et al. Incidence, risk, and prognostic factors of nosocomial pneumonia in mechanically ventilated patients. Am Rev Respir Dis 1990; 142:523-8.

7. Rello J, Ausina V, Castella J, Net A. Prats G. Nosocomial respiratory tract infections in multiple trauma patients. Influence of level of consciousness with implications for therapy. Chest 1992;102:525-9.

8. Fagon J-Y, Chastre J, Domart Y, et al. Nosocomial pneumonia in patients receiving continuous mechanical ventilation. Am Rev Respir Dis 1989;139;877-84.

9. Celis R, Torrs A, Gatell JM, et al. Nosocomial pneumonia. A multivariate analysis of risk and prognosis. Chest 1988:93:318-24.

10. Pennington JE. Penetration of antibiotics into respiratory secretions. Rev Infect Dis 1981;3:67-73.

11. Bodem CR, Lampton LM, Miller DP, et al. Endobronchial $\mathrm{pH}$. Relevance to aminoglycoside activity in Gram-negative bacillary pneumonia. Am Rev Respir Dis 1983; 127:39-41.

12. Mandell LA, Nicolle LE, Ronald AR, et al. A multicentre prospective randomized trial comparing ceftazidime with cefazolin/tobramycin in the treatment of hospitalized patients with non-pneumococcal pneumonia. J Antimicrob Chemother 1983;12(Suppl A):9-20.

13. Stevens RM, Teres D, Skillmann JJ, et al. Pneumonia in an intensive care unit: a 30-month experience. Arch Intern Med 1974;134:106-11.

14. Bryan CS, Reynolds KL. Bacteremic nosocomial pneumonia. Analysis of 172 episodes from a single metropolitan area. Am Rev Respir Dis 1984;129:668-71.

15. Hilf M, Yu VL, Sharp J, Zuravleff JJ, Korvick JA, Muder RR. Antibiotic therapy for Pseudomonas aeruginosa bacteremia: outcome correlations in a prospective study of 200 patients. Am J Med 1989;87:540-6.

16. Johnston BL, Forward K, Marrie TJ. Nosocomial pneumonia. Chest Surg Clin North Am 1991;1:337-68.

17. Gross PA. Epidemiology of hospital-acquired pneumonia. Semin Respir Infect 1987;2:2-7.

18. Chastre J, Fagon JY, Gilbert DC. Diagnosis of nosocomial pneumonia in intensive care units. Eur J Clin Microbiol Infect Dis 1989;8:35-9. 


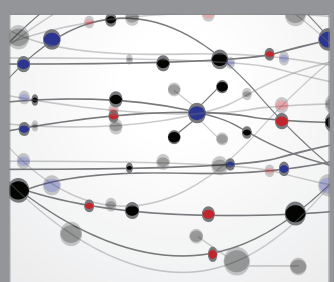

The Scientific World Journal
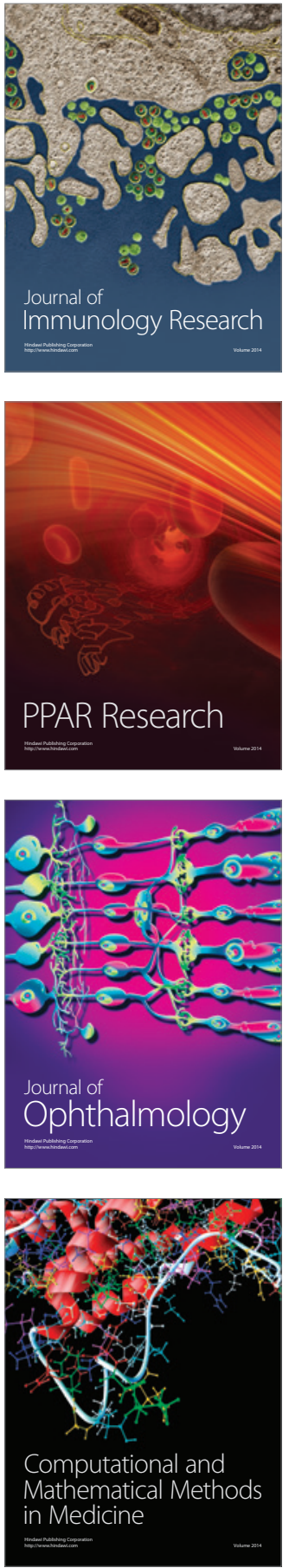

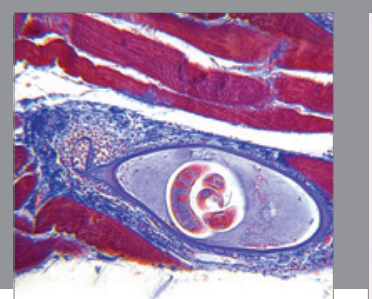

Gastroenterology Research and Practice

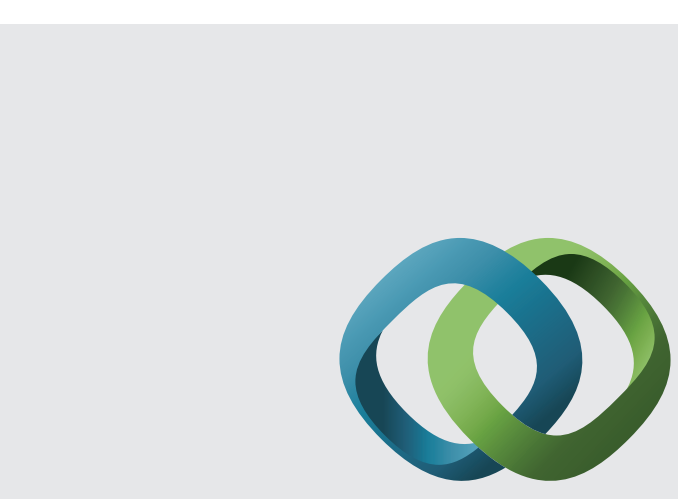

\section{Hindawi}

Submit your manuscripts at

http://www.hindawi.com
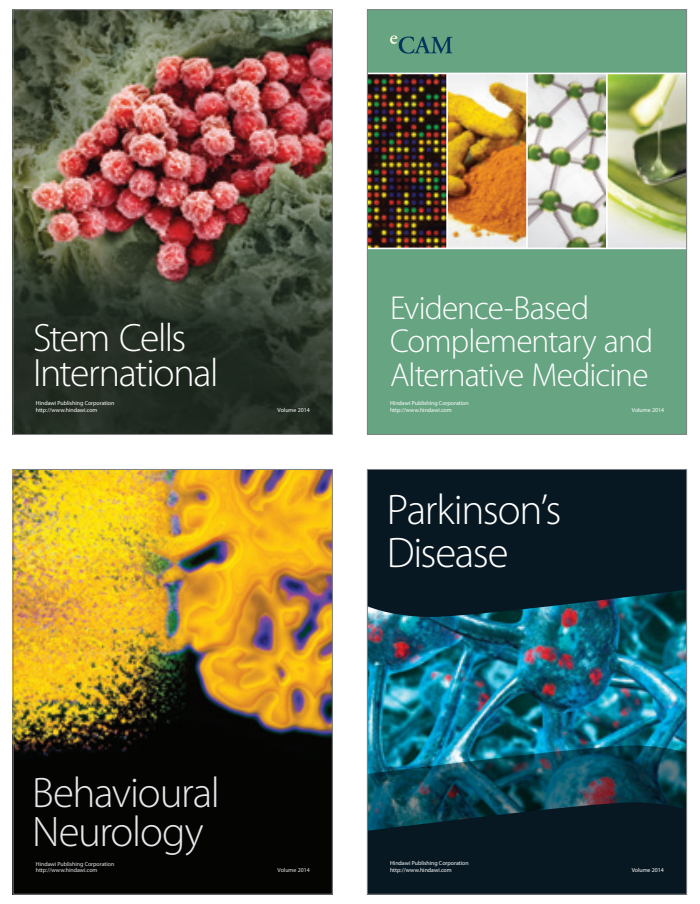
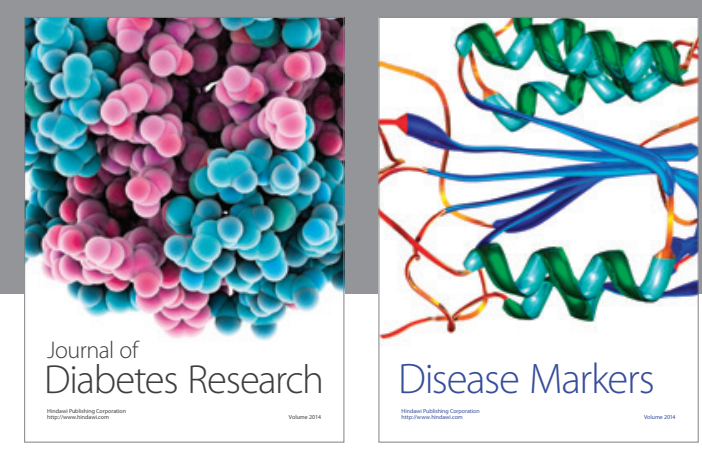

Disease Markers
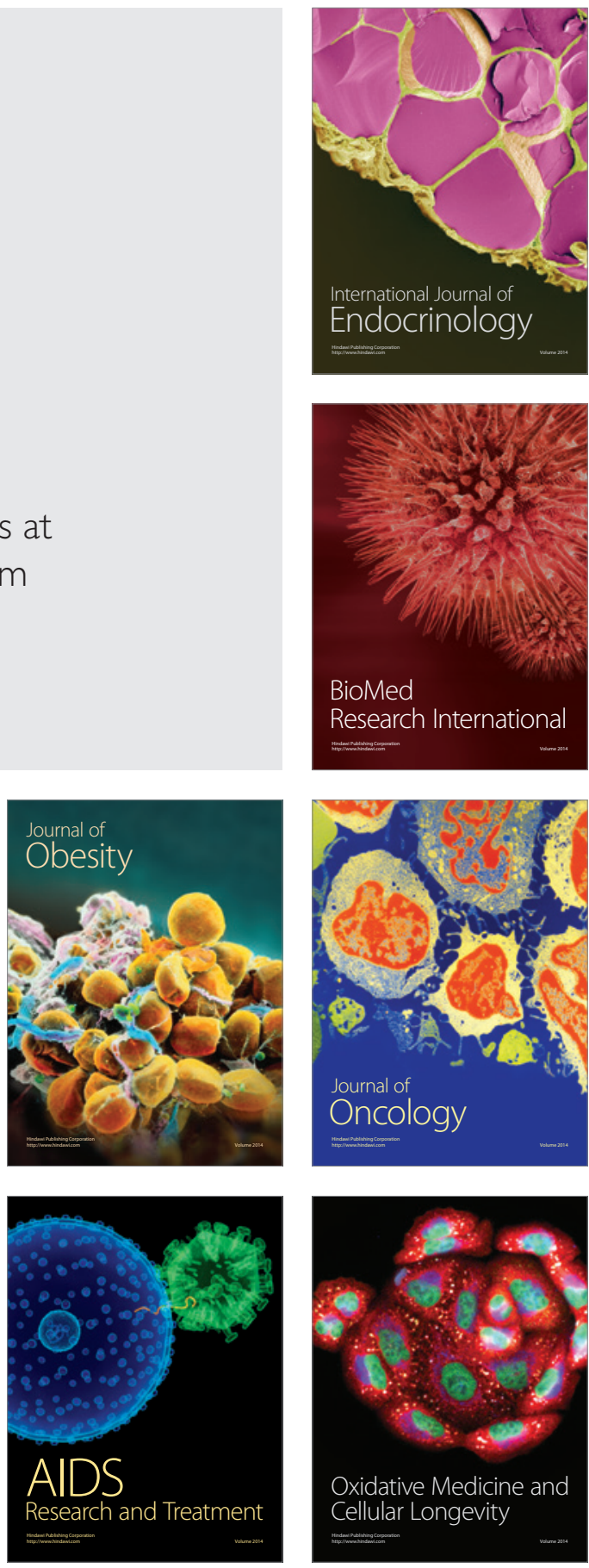